\title{
Nonprofits and Park Provision in Los Angeles: An Exploration of the Rise of Governance Approaches to the Provision of Local Services*
}

\author{
Stephanie Pincetl, University of California
}

Objectives. Park planning and development in the Los Angeles metropolitan area offer an opportunity to explore the assertion that "Western cities are now being managed, organized and governed in different ways" leading to a "new urban politics," and the suggestion that urban regime theory captures cultural and civil societal influences and organizations in its descriptions of coalitions and their roles in promoting places. Methods. This article examines park provision in Los Angeles historically and in the contemporary period through interviews and current documents, as well as through newspaper articles and park bond proposition language. Results. The resulting analysis suggests that civil society organizations such as nonprofits act in quite similar ways to traditional urban regime business interests. Conclusions. Nonprofits should be examined for their roles in creating a new urban politics, including structures of governance. Additionally, in the environmental area, these organizations have become significant actors in determining land uses.

Park planning and development in the Los Angeles metropolitan area offer an opportunity to explore the assertion that "Western cities are now being managed, organized and governed in different ways" leading to a "new urban politics" (Hall and Hubbard, 1998:1, referring to Cox and Mair, 1988; Kirlin and Marshall, 1988) involving, in part, the rise of urban entrepreneurialism and competitivity among regions. In the United States, local government, local finance, politics, land and economic development, and social service provision have been deeply affected by a complex conjunction of circumstances, including the acceleration of globalization, the increasing devolution of government authority to states and localities and the hollowing out of the state, as well as the de-statization of politics (see, e.g., Ward, 1996:427; Jessop, 1995; Sassen, 1996).

*Direct correspondence to Stephanie Pincetl, Visiting Professor, Institute of the Environment, 610 Charles E. Young Dr. E., Hershey Hall, University of California, Los Angeles, CA 90095-1496<spincetl@ioe.ucla.edu〉. The author will share all data and coding material with those wishing to replicate this project. Thanks to Andy Jonas for his encouragement and interest in this research, and for his helpful comments. Thanks also to Bob Lake for his intellectual imagination and rigor. 
Much attention has been paid to the proactive promotion of local economic development by local government in alliance with other privatesector agents, giving rise to the concept of urban regimes (Stone, 1989; Elkin, 1987; Peterson, 1981) and analyses of the ways this public/private cooperation works in different places. These alliances are associated with an organizational and institutional shift from urban government to urban governance (Hall and Hubbard, 1998:4; Rhodes, 1996; Macleod, 1997) wherein a "complex process of negotiation, coalition formation, indirect influence, multi-institution working and public-private partnership" (Painter, 1998) approach to local public decision making prevails.

An earlier political science literature (Lineberry and Sharkansky, 1978) had already demonstrated how private-sector elites, elected decisionmakers, and municipal bureaucracies interacted to provide public services in ways that reflected specific urban political systems. Lineberry and Sharkansky anticipated the urban regime approach by developing a theory of power in the city that was highly dependent on the history, culture, politics, and economy of the city in question. Of course, it is important to also recognize that urban regime theory is "partly a development of the critical pluralist community power tradition of the 1950s and 1960s" neopluralist traditions (Davies, 2002:3). Lindbloom, for example, recognized that governments in capitalist countries require economic growth and thus economic interests are significant in governmental decision-making considerations (1977). Others, such as Okun (1975), were more sanguine and while discussing the tensions between the political principles of democracy and the economic principles of capitalism, and argued the U.S. basic system emerged as a viable, if uneasy, system, particularly if progressive taxation, transfer payments, job programs, and so forth were forthcoming.

Urban regime theory emerged "because it dispenses with the stalled debates between elite hegemony and pluralist interest group politics" (Lauria, 1997:1). Of primary interest for Elkin has been the continued analysis of the division of labor between market and state with the following defining axes of urban politics: public and private growth alliances, electoral coalition strategy, and the structure of bureaucratic service provision (Lauria, 1997:1). Elkin (and Stone) both have been embraced, as the concept of urban regimes is now widely utilized and criticized, and despite its shortcomings it has been used for research in the United States and in cross-national research. Criticisms of urban regime theory include its overemphasis on the politics of local business interests at the expense of other broad-range local practices and interests that contribute to local politics (Painter, 1998). Urban regime theory is also somewhat limited in its capacity to address scale: local politics and policies are often embedded in larger state-level mandates or politics, as well as national ones. Additionally, localities are affected by economic changes and forces that operate beyond the sphere and scope of localities (Logan and Molotch's growth machine approach captured some of this dynamic). Gibbs and Jonas 
suggest that the environment is yet another area about which urban regime is naïve- a problem linked to urban regime theory's difficulty in addressing larger regulatory processes of after-Fordist social regulation (2000:301).

Finally, urban regime theories often fail to capture cultural and civil societal influences and organizations in their descriptions of coalitions. Civil society institutions beyond political parties, such as charitable organizations, participate in attempts to mobilize state resources and/or to influence policymakers and business interests for programs and policies. Much like business coalitions, they lobby local elected officials, work with local bureaucracies, and mobilize to both influence state-level political bodies and to divert public support for projects. They may enter into coalitions with business interests, other nonprofit organizations, or create alliances with the structure of bureaucratic service provision to move their agendas forward. They create competitive funding programs and compete for those funds. Those places lacking this civil society infrastructure tend to be less well equipped in parks and other amenities, such as concert halls and museums - all part of creating an economically thriving community, indeed an entrepreneurial city.

My intent in this article is to propose that in refining the analysis of urban politics and urban regimes, the role of the nonprofit sector as an active and effective actor in local urban regimes ought to be considered as it can play an important part in determining land-use allocations; it is an important player in the new urban politics and the emerging structures of governance suggested by Jessop (1995). In the U.S. context, the land-use allocation question is central to analyzing urban regimes and their effectiveness as land use is one of the main prerogatives of localities. Land-use determinations by locally elected officials determine the character of localities, including types of housing available (single family vs. multiple family), the existence of industrial manufacturing, commercial, or retail services, parks and open spaces, schools, and so forth. Land-use planning is the key to a locality's prosperity, demography, and success. Hence much of the focus of urban regimes has been on influencing land-use allocations (Elkin, 1987). But land use is of interest to other urban actors as well: environmental nonprofits, health care and social service nonprofits, arts and gardening groups- the list could go on and on.

I use the case of parks and park planning in Los Angeles to suggest how environmental nonprofits have effectively become partners in the local urban regime and in local governance arrangements. Although there remains a great deal of empirical research to be done to fully trace the rise of power of environmental nonprofits in the local politics of land-use allocation generally, and in Los Angeles specifically, sufficient evidence exists to point to the emergence of environmental nonprofits as important players in the governance of the Los Angeles metropolitan area and to believe that Los Angeles is not an isolated case. 
The rise in involvement of the nonprofit sector that has come about as a result of the forces enumerated above has been analyzed in the areas of welfare services provision, health care, and the arts (Staehli, Kodras, and Flint, 1997; Wolch, 1990). Yet nonprofit involvement in these sectors does not seem to have been much taken into account in the literature on the new urban politics as "economic processes are often regarded as providing a more basic level of explanation, while cultural and political change is interpreted as a dependent variable which is caused or heavily conditioned by the economy"(Painter, 1998:266). As Painter points out, the view of the economy as foundational is flawed as it is based on a false division between economic, cultural, and political realms. Economic processes do not occur independently of other social changes (Painter, 1998:266). Hence the ways social services are provided, for whom and where-including parks, recreation, and open space - are as significant as the ways metropolitan areas are managed by the new urban politics. "In some localities ... forms of governance have emerged that are built upon activist models of citizenship and produce progressive approaches to planning, the environment, and of course, economic development" (Gibbs and Jonas, 2000:306). Such examples might include land trusts created through applying for state funding, but managed by a nonprofit organization.

Urban amenities - the arts, shopping, a clean environment, parks, and open spaces-play an important part in creating attractive cities, cities that will be successful in promoting their status as places to invest and to live: in their competitivity. As Justin O'Connor points out, "while the cultural industries are being approached as part of a wider repositioning by many cities, there has been very little research as to how these industries actually operate" (1998: 225). Yet the arts are a widely recognized attribute for urban competitiveness (see Boeing's recent decision to move to Chicago where city fathers actively promoted Chicago's vibrant and longstanding cultural institutions). And even though there is wide awareness that a "good" environment is an important attribute of making places attractive to business and investment, how that "good" environment is created is also insufficiently researched. Just as for the arts, nonprofit involvement in promoting urban environmental quality is certainly significant. Parks and open space, clean air, and attractive waterways are visible components of attractive urban regions, and should be added to the understanding of how localities promote economic development in a competitive globalized world. In sum, the emphasis on traditional economic analysis and processes has tended to neglect the importance of civil society as a participant in governance structures.

I will first provide an overview of the national historical context that has shaped urban parks, then turn to park planning and provision for the Los Angeles metropolitan region. I will explain some of the fiscal pressures facing the locality that have given rise to the involvement of environmental nonprofits. I will then turn to how the environmental nonprofits have shaped parks and park planning in the region, their involvement in creating 
structures of governance for the creation and management of parks and open spaces, as well as their growing involvement as members of the local urban regime. In so doing, environmental nonprofits have also influenced the definition of parks and open space in the area, and shaped the ideology of what kinds of parks and open spaces are appropriate and where, and affected land-use decisions through mobilizing fiscal resources for the purchase of land and/or the refurbishment of park and recreation facilities. The park and open space ideologies motivating nonprofit involvement carry with them normative values about nature and human/environmental relations (and the proper use of land), which I will briefly elucidate. In conclusion, I will suggest some areas for further research.

\section{Ideologies of Parks and Open Space}

\section{Parks and U.S. Cities}

The development of parks, open space, and recreation facilities in U.S. cities is inextricably connected to the historical development of the American city and its land uses. The phenomenal acceleration of urbanization in the late 19th century and the problems of overcrowding and insalubrious housing conditions led to a reform movement that included advocacy for parks. New York, for example, had reached a population of 1 million by 1880 ; Chicago's population increased by 600,000 in the decade between $1880-1890$. There were repeated epidemics, and tenement buildings often had no light, air, or sanitary provisions (Foglesong, 1986). Parks, recreation, and open-space planning emerged as antidotes to the unhealthy city, providing access to cleaner air, nature, and open space. This new type of land use also was seen as a mechanism that would help ensure greater social stability, healthy families, and healthy neighborhoods (Olmsted in Sutton, 1971; Rosenzweig, 1983).

Following the construction of Central Park in New York in the 1850s, large urban parks were built before the turn of the century in Boston, Cleveland, Baltimore, Saint Louis, San Francisco, and Chicago. Parks were built to provide lungs for the city, places for workers to relax outside the world of work (Sutton, 1971), as well as to boost the local economy. Parks projects employed many people, and once constructed contributed substantial value to adjacent properties.

Over time, social reform objectives became increasingly embedded in the design of parks. The parks and playground movement of the late 19th century and beginning of the 20th advocated the reshaping or restricting of working-class, often immigrant, leisure-time practices in order to mold the dangerous classes into reliable Americans (Rosenzweig, 1983:224). Team sports became increasingly popular and thought of as activities that would inculcate positive American attributes such as teamwork and participation. In Chicago, for example, as Draper explains, there were the "pleasure 
grounds," which had been completed over the years since 1869; however, the newer turn-of-the-century parks were to be smaller and to serve as neighborhood recreation centers in some of the city's most congested tenement areas. These were to combine the playground with certain aspects of the large pastoral park, including lawns, flowering shrubs, trees, playing fields, sandboxes, showers, and to offer structured recreational, cultural, and social programs for people of all ages in immigrant communities (Draper, 1996:101-03). Chicago's parks became a general standard adopted throughout the country (Draper, 1996:106).

In Rosenzweig's study of Worcester's park building, similar themes emerge: social reformers and others see recreation and parks as a means of social control; proper play behavior (often in the form of team sports) would ensure proper behavior in other areas of social life (Rosenzwieg, 1983:143). Stanley Hall, president of Clark University, and one of the founders of American psychology, further theorized that children's play was essential to normal child development, and that play facilities could shape proper social behavior (Rosenzwieg, 1983:143). In Chicago, Boston, and New York, leaders "agreed that urban working-class children, especially the offspring of immigrants, needed to be rescued from the unsafe and socially and morally destructive conditions in city streets, tenements, saloons, and penny arcades" (Draper, 1996:108). Further, "park officials and recreation directors were intent on controlling and molding the social behavior of residents in immigrant neighborhoods" (Draper, 1996:110).

Parks and open spaces in cities had become necessary ingredients to making great cities (embraced by the city beautiful movement, then by Progressives), to the betterment of the physical spaces of cities and human health, to improving child development, to accelerating Americanization, and for social control (Cranz, 1989). Additionally, landscape architects and early ecologists such as Frederick Law Olmsted and his contemporary Jens Jenson advocated for parks not only for providing fresh air and supplying aesthetic pleasure through beautiful landscapes, but also for ecological restoration (Jordon, 1994).

Clearly (to paraphrase Raymond Williams (1980)), the history of parkstheir shape, form, function, and financing - reflects a great deal about the values of the society, about human relations with nature in the city, and recreation's role in American ideologies of citizenship and acculturation.

Certainly, there have been numerous developments since the turn of the century with respect to parks and park policy; nevertheless some of the basic tenets of this earlier period can still be discerned in park policy in Los Angeles today.

\section{Park Planning in California and Los Angeles}

Local park planning and construction in Los Angeles has had a long and arduous past. In 1854, wealthy city councilman Major Hancock suggested 
an ordinance that would have subjected land sales of city property (the old pueblo lands) to alternate city lots only (35 acres each) in order to assure sufficient land for "pleasure grounds, college grounds, grounds for academics [sic] of learning, public gardens and public squares" (in Hjelte, 1977:52). But pressure for development quickly overcame this suggestion, and no parkland provisions were made by the city.

In 1896, Griffith J. Griffith, a successful gold speculator, gave the City of Los Angeles five square miles of rugged land for "a place of recreation and rest for the masses, a resort for the rank and file, for the plain people" (in Hjelte, 1977:1). At that time the city council was doubtful about accepting the gift, concerned about the wisdom of removing the land from the tax roles. Further, the city had no money to police and maintain the park until Griffith bequested a million dollars for a park trust fund. Griffith, in advocating for parks, argued that park space could be the lungs of the city, could relieve class tensions, and could be tied directly to comprehensive city planning: "Public parks are the safety-valves of cities," said Griffith (Hise and Deverell, 2000:16). Wealthy local businessmen such as John Bixby, oil tycoon and founder of Long Beach, also created other parks through gifts. In this manner the city acquired Elysian, Westlake, and other handsome parks (Hjelte, 1977). In 1889, a Park Commission was established; in 1904 a Playground Commission was created and the city began to build a number of urban playgrounds (Hise and Deverell, 2000). Griffith and others continued to advocate for greater parklands, scenic parkways, cultured landscapes, and the preservation of wilder places for public recreation. Turnof-the-century Progressivism integrated the issues of social hygiene and the importance of the environment on the individual. As Dana Bartlett, settlement house founder, Methodist minister, and park advocate, put it "the fairer the city, the nearer to Nature's heart the people are brought; the more easily they are governed" (in Hise and Deverell, 2000:12). Ideas about the benefits of parks in LA mirrored national thinking.

In the mid-1920s the city had over 200 separate parks encompassing nearly 5,300 acres - of which Griffith had donated about 3,000 acres. However, Griffith Park was considered too rugged for recreation, and Elysian Park was almost unused for lack of access. This meant that the city had only about 400 acres of parklands available for everyday use (Hise and Deverell, 2000:29). The overall total, at the time, compared favorably with that of other metropolises, but fell far short of the planners' aspirations for Los Angeles (Fogelson, 1993:260). "By the 1920s, even the Chamber of Commerce conceded that Los Angeles desperately needed more parks and playgrounds" (Fogelson, 1993:258). Migration to the region, the selling off of pueblo land for subdivision, and the expansion of the metropolis meant that to acquire additional open space for the city, other sources of land and funds would have to be tapped. Planners turned to persuading large-scale developers to dedicate a few parcels for a park, arguing it would enhance the value of the adjacent lots. But few developers were cooperative and 
municipal authorities did not feel they could spare the money to purchase parklands. Up to 1930 , attempts to provide parks, parkways, and a civic center succeeded only where they were adjusted to the priorities of physical improvements (like urban infrastructure), low taxes, and automobile traffic.

The 1930 Olmsted Bartholomew plan for the Los Angeles region, commissioned by the Los Angeles Chamber of Commerce, was the culmination of two decades of advocacy by Park Commission members and others, including Kate Bassett, a member of the Los Angeles City Planning Association (Hise and Deverell, 2000:20). It was a comprehensive, elitedriven and financed, park and scenic parkway plan that encompassed Los Angeles County, beaches, and surrounding mountains, along with a park bond funding proposal. Yet once the scope and magnitude of the proposal was fully understood by chamber members, the majority balked at the cost and the call for a regional park authority, and the report was never widely released. Although there was indeed concern about the city's lack of parks and open spaces among planners, social reformers, and the economic elite, dislike of taxation and the idea of a regional government potentially determining land allocation superceded concern about people's life spaces.

The plan was not adopted, but it did become a point of reference for subsequent park-planning efforts in Los Angeles County. In the 1930s, Los Angeles park director George Hjelte adopted the structure of the report to press for protection of the shoreline and beach access; the County Board of Supervisors's 1945 commissioned report, echoing the Olmsted Bartholomew plan, recommended a county commission or district to coordinate planning and programs, acquire additional land for recreation, and so on. In the 1960s and 1970s, the plan was again revived and served as the basis for a series of regional investigations into open space in the five-county metropolitan region undertaken by the landscape and planning firm EDAW (Eckbo, Dean, Austin and Williams) (Davis in Hise and Deverell, 2000: 49-50). Today, as the success of Hise and Deverell's Eden by Design demonstrates, the power of the Olmsted Batholomew plan remains, and many decry the missed opportunity for creating a vast regional network of open spaces, scenic parkways, and stunning view sheds the plan would have provided. In fact, the plan is still referred to in today's efforts to preserve open spaces and create parks in Los Angeles and the region.

\section{The Precursors to Nonprofit Involvement in Urban Parks and Open Space}

The first half of the 20th century saw slow, steady land acquisitions in California, primarily for recreation purposes, with the state government providing increasingly more funding. The philanthropic tradition was strong in the state too, particularly in the early 20th century, with an emphasis on land donations or purchases through fund raising. 
With the rise of the environmental movement in the 1960s, economic prosperity, and relatively abundant revenues, local, state, and federal funds for local open-space preservation grew tremendously (Press, 1999). Awareness of the importance of open spaces at the local level mirrored the availability of funds. The State of California mandated the cities and counties to adopt "open-space elements" in their general plans in 1970 (Press, 1999). How this shift affected parkland acquisition in the Los Angeles metropolitan area has not been documented, but all evidence shows there was not much acquisition (Harnik, n.d.). Literature on parks and park planning in the region does not go much beyond nostalgically revisiting the Olmsted Bartholomew plan. Nevertheless, regardless of increases in the availability of funds that occurred in the magical period 1960-1978, the region remained park-short compared to other major metropolitan areas in the country.

Further, even if during the "first environmental epoch" (Daniel Press's term) the region might not have availed itself of the fiscal resources for creating additional parks and open spaces to the extent other places did, the advent of Proposition 13, the property-tax-cutting ballot initiative passed in 1978, coupled with federal funding declines for metropolitan areas, caused parks and recreation budgets, along with funds for other public services, to decline dramatically.

\section{Proposition 13}

As California columnist Dan Walters recently wrote in the reputable Sacramento Bee, Proposition 13 has "changed the political dynamics of the state in dramatic and lasting ways. It marked the end of a three-decade-long period of expansive government that had even survived Ronald Reagan's governorship" (Walters, 2001:3). Proposition 13 was a reaction to rapidly increasing property taxes that were indexed to property values. The local property assessment process had been turned into a nondiscretionary administrative function by legislation in 1967, putting residential assessments on a computerized auto-pilot that required every parcel, commercial or residential, to be reassessed every three years at 25 percent of market value (Schrag, 1998:134-35). Thus, as land prices kept escalating so did property taxes, particularly residential property taxes.

Proposition 13 was composed of three principal elements.

1. It limited the general property tax rate to 1 percent of the full value of property and limited the reassessment of property to no more than 2 percent annually, except for cases of a change in ownership or new construction.

2. It assigned the state the responsibility of allocating the proceeds of the property tax. 
3. It increased the ability of the electorate to vote on certain local tax increases and required any special tax to be approved by two-thirds of the voters. No new ad valorem property taxes could be imposed (Silva, 1999:32).

Proposition 13 effectively undermined home rule because property taxes are now set by statute, and revenue distribution is controlled by the state (Silva, 1999:ix). "[I]t led to a massive shift of financial and operational authority from locally elected government and school officials to Sacramento. It altered land-use policies of local governments, as they sought to maximize commercial, sales tax-producing projects" (Walters, 2001). Under Proposition 13, the state has the power to reallocate property tax revenue among cities, counties, school districts, and special districts. During the recession of the early 1990s, the state reallocated approximately 25 percent of the total property tax revenue from cities and counties to school districts. None of this revenue has been permanently restored, though a small portion has been returned on a year-by-year basis (Sprawl Hits the Wall, 2001:37). For counties and cities statewide, it has meant that "the share of county revenues that counties are authorized to raise themselves has dropped from 50 percent to 20 percent, for cities; the share has dropped from 66 percent to 43 percent" (Lyon in Shires, 1999:iv). Between 1982 and 1997, the share of local budgets derived from property and sales tax revenues in metropolitan Los Angeles dropped from 30 percent to 23 percent, while the share derived from fees rose from 14 percent to 24 percent.

For the City of Los Angeles Department of Recreation and Parks, which is a semi-independent department, allocated $\$ 0.0384$ per tax dollar by the 1925 City Charter, this represented a severe blow. Los Angeles County Parks receives its funding from the county general fund. Both have had to scramble to find additional funding to make up for the loss of property tax revenues. A snapshot example of the effect on the City of Los Angeles demonstrates the change: the pre-Proposition 13 property tax rate (based on 25 percent of market value) for $1977-1978$ was $\$ 2.88$, in $1984-1985$ it was $\$ 0.0552$, in $1985-1986$, it was $\$ 0.0288$, and in $1987-1988$ it was $\$ 0.0180$ (Attachment 1 to Mayor Bradley's budget letter to the City Council of Los Angeles, 1985-1986, 1988:A-26, A-33).

In addition, even as local governments have become increasingly dependent on a diversity of funds, including state funds, state funds themselves have become increasingly earmarked for some specific set of programs, often as a result of other subsequent initiatives (Pincetl, 1999). For example, in 1989, Proposition 98 was passed, guaranteeing schools a minimal level of funding from the state, locking up at least 40 percent of the state's general fund and obliging the state legislature to rely on local property tax revenues from cities and counties to ensure the 40 percent is met and there is money left for other programs. As localities scrambled to then 
identify new sources of additional taxation and income, anti-tax ballot measures quickly followed suit. For example, localities found that assessment districts were a source of additional revenue, but Proposition 218, passed in 1996, says that no local tax, fee, or assessment is permissible without a twothirds majority vote. In some instances, a vote of the affected property owners is required, but only after there has been an engineer's analysis demonstrating that the properties on which new charges would fall would actually benefit in proportion to the charges. Votes would also be property weighted, meaning that owners of large amounts of property would get more say (Schrag, 1998:165-70).

In the end, the share of revenues cities and counties are free to allocate represents only about $30-40$ percent of their revenues, the state determining how the rest of the local tax gets spent, and how much it will keep (Silva, 1999). Proposition 13 cut property tax revenues absolutely, forcing cities and counties to develop complex new revenue streams. Initially, the intensification of fiscal land-use zoning was the way localities tried to recapture tax money through increased retail activities for sales tax revenues. Gradually, cities have also developed new and higher fees-such as raising fees charged for remodeling permits-developing payroll expense taxes, higher sales taxes, higher parking ticket fees, extending business taxes to businesses not previously taxed, and relying on state motor vehicle license fees and state funds as well as counting on federal general revenue sharing for substantial funding of recreation and parks and libraries (Mayor Bradley's budget letter to the City Council, April 1, 1984). All in all, these new taxes have been characterized as more regressive in nature, compared to the property tax, and today fees and other charges bring in the lion's share of revenue, despite the continuing fiscalization of land use (Sprawl Hits the Wall, 2001).

By the early 1980s, cities and counties in California had suffered significant revenue losses, and the state itself experienced an end to its expansive role that had encouraged and funded parks and open-space development at all levels. The state was undergoing profound economic transformation as well as a fundamental change in the ways localities were financed.

\section{A Reorganized Urban Regime}

Sixteen years of Republican rule followed Proposition 13, as well as a serious recession in the 1990s. There had built up tremendous frustration and demand for the expansion of urban and rural parks. With hugely increased urbanization in southern California, questions of land allocation were particularly polarized around preservation for endangered species protection (southern California has the most endangered species in the continental United States) versus continued urban development (Fulton, 
1997; Jonas, 1997; Gibbs and Jonas, 2000, Pincetl, 1999). Little money was available from state or local general funds for parks or habitat protection, so the environmental nonprofit sector turned to the ballot box to raise revenues, initially at the state level.

The strategy was developed in the late 1980s by environmental and health organizations. These organizations intervened in the political process of determining how resources would be allocated. The California Planning and Conservation League (PCL), directed by Gerald Meral, previously in the Jerry Brown Administration, developed a set of inventive campaign funding tactics and ballot initiatives to finance the acquisition and development of park and recreation areas. Meral's first ballot measure (Proposition 70) in 1988 included some 60 individually defined projects, each with a specified amount, in every corner of the state. Never before had this approach been used. Previously, all park bond proposals had been proposed by the legislature, and the general purposes were outlined but it was always left to the elected body and state agencies to decide how and where to spend the funds. PCL invented a radical new approach to ballot initiatives: each of the specific projects was chosen with an eye to maximizing local voter appeal and in negotiations with local environmental groups and others, from homeowner associations to local governments (Schrag, 1998).

In essence, PCL began to organize a new approach to funding public amenities that years of state retrenchment, devolution, and tax cutting had left short of funds. Meral's approach involved negotiating among a complex set of partners: environmental groups, state and local agencies, homeowner groups, cities and counties, and private interests. Each group was expected to contribute either money or signatures in proportion to the benefits received (Schrag, 1998:218). As the state Chamber of Commerce, the Farm Bureau, and other agricultural groups complained, PCLs process abandoned the normal process of having spending proposals developed by the legislature and professionals, replacing them with special interest groups, negotiating in private (Schrag, 1998). Meral's brilliance was to simply replicate what the older urban regime interest groups had always done: entering into the political fray to direct investment in their direction, but now it was for public amenities like parks, and the leaders included environmental nonprofits. PCL innovated a new approach to funding state and local amenities, which was then adapted to Los Angeles by a former PCL staff person, Esther Feldman.

Ms. Feldman came to the Los Angeles region to devote herself to raising money for parks in the region, initially for the preservation of the Santa Monica Mountains, which had been declared a federal National Recreation Area in the 1970s, but with insufficient funds allocated to purchase significant amounts of land. The mountains, under the jurisdiction of Los Angeles and Ventura Counties, were prime real estate for development, and Los Angeles County was a development-friendly jurisdiction. As a result, the state, under Governor Jerry Brown, created a state agency, the Santa Monica 
Mountains Conservancy, which would act to purchase and manage Santa Monica Mountains lands, supplementing the languishing National Recreation Area efforts. The mountains, transversing Los Angeles County right at the urban fringe, contain extraordinary habitat and wilderness. The Conservancy, governed by an appointed commission, was free to enter into deals to purchase land, as well as to apply innovative land-use tools such as scenic easements.

The Conservancy received state funding, but urbanization pressure, lax environmental protection of open-space lands, and high prices meant that Santa Monica Mountains lands were being quickly snapped up and developed, particularly in Los Angeles County. Under the fiscal austerity measures ushered in by Republican governors (Pincetl, 1999) and reinforced by economic recession, the Conservancy could not meet its goals, and sensitive habitat continued to be developed. Feldman had learned from Meral that in order to obtain protection of one area, the pot had to be sweetened so that there would be broad support-a ballot initiative that could reward many was more likely to succeed. Further, due to the requirements of Proposition 13, a two-thirds majority was necessary for a straight bond initiative. Santa Monica Mountains Conservancy head, Joe Edmiston, had tried getting park ballot initiatives passed, and had failed by as little as one-half of a percentage point. So Feldman devised an innovative strategy for funding - it would not be a straight bond initiative. She figured out that the Landscaping and Lighting District, created by the legislature in 1972, offered a tremendous opportunity to raise money for parks. Districts can levy special fees if it can be proven that they enhance property values. However, such an additional fee needed the go-ahead from the state legislature since it would involve the State Street and Highways Code. Enlisting the support of a local Republican state legislator to get the concept approved by the legislature, environmentalists were then able to convince the County Board of Supervisors to place Proposition A on the ballot (Edmiston, 2000) The measure passed by 64 percent—still 1 percent shy of what would have been required by a two-thirds majority vote. As explained above, however, assessment district taxes are now much more difficult to use.

Edmiston and Feldman, as well as local officials from many jurisdictions and agencies, had joined together to craft a Meral-like ballot initiative to fund open space and parks acquisition on a countywide basis. In this manner, a concern about habitat preservation was broadened to include an array of park and park programs so that there would be enough support to get funds and endorsements. Park bureaucracies and local politicians across the county enthusiastically endorsed the ballot initiative, as did homeowner associations and environmental groups. The complex array of partners and beneficiaries, including a provision that a part of the money would be available on a competitive basis to qualified community-based organizations, was a new strategy to get parks and open-space amenities (including 
recreation facilities) funded. ${ }^{1}$ It involved the nonprofit sector figuring out how to create a public/private partnership to access and leverage public funds for the programs the participants wanted to have created. Although the partners represent new and different actors than conventional urban regime partners, the processes by which they mobilized resources is much the same. Arguments for expanded funding for these amenities ranged from the need to protect habitat to the importance of providing safe and structured recreation opportunities for disadvantaged children and neighborhoods (an argument harking back to an earlier period). In fact, Proposition A was entitled "Safe Neighborhood Parks, Gang Prevention, TreePlanting, Senior and Youth Recreation, Beaches and Wildlife Protection." At the county level, 80 percent of the money received each year goes to specified projects (those projects that had been hammered out during the process of negotiation over the ballot initiative language); the rest is split between administration for the district and a per parcel allocation to cities to fund maintenance of projects, and a small pot for a competitive grants program. However, because funds are allocated based on an assessment district formula, funding reflects the number of parcels served by a facility. Those cities in the county, or county unincorporated areas, that lack parks or recreation facilities do not qualify for any of the Proposition money. Consequently, the widely, but thinly, distributed parcel-based park money has unavoidable built-in inequities.

However, because this approach proved so effective, the City of Los Angeles followed suit with Proposition K in 1996, before the passage of Proposition 218. Much of the Los Angeles city Proposition K monies were also preallocated through negotiation and compromise, and a small amount of competitive project funds were set aside to be distributed through an appointed commission, the Commission on Youth, Children and their Families. In interviews with commissioners and petitioners, it appears that even this money is structurally more easily available to conventionally defined groups and organizations for traditional activities: Boys and Girls Clubs, enhanced baseball-field lighting, and the construction of new sports facilities (today in LA it is soccer that is the predominant activity) (Ward, 2001).

Each of these two main sources of additional funds for parks, open space, and recreation have not been much examined with respect to who gets what amenities where. Although there is general acknowledgment of a tremendous need for additional amenities, trying to fit everyone's needs into such mechanisms leaves certain groups behind. But more fundamentally, the participants involved in creating these funding mechanisms, and their

\footnotetext{
${ }^{1}$ The list of groups funded by the competitive category for Proposition A, obtained by the author from the county, as of December 12, 2001, includes such groups as the Mar Vista Youth Center, New Directors for Youth Graffiti Restoration Program, Mural Art Tem Hollywood, Cold Creek Restoration, a few schools, and other restoration projects.
} 
insertion into large-scale land-use decision making, have not been well understood. Upon examination, they appear to be part of an evolving new urban regime in Los Angeles and the county that is composed of public and private partners coalescing to determine land allocation for park and open space uses.

Ester Feldman and Joe Edmiston initially come from a habitat protection mission. Efforts to preserve the Santa Monica Mountains, well-publicized efforts to create a Los Angeles River Parkway, and the increasingly successful attempts to create a very large park in the Baldwin Hills area of Los Angeles are part of this approach to the city: preserve and restore ecosystems whenever and whereever possible. However, to get support for habitat protection and restoration, there must be a quid pro quo in other parts of the city; hence programs for what appear to be structured recreation in low-income communities of color. Edmiston's thinking seems to replicate that of earlier parks and recreationists who thought structured recreation was most suited for low-income, immigrant neighborhoods. Edmiston justifies his position in two ways. The first is that the best habitat is at the urban fringe, and it contains precious biodiversity and should be preserved (this also happens to be where affluent neighborhoods are). This contention is indisputable. Second, Edmiston points to academic studies that argue that different ethnic groups have different preferences for parks, recreation, and open space (Edmiston interview, citing the somewhat controversial article by Hester, Blazej, and Moore, 1999). Such groups prefer active sports facilities and facilities where they can conduct group activities. More research needs to be conducted on the precise distribution of amenities, but a reading of the ballot initiatives indicates this distribution is indeed the intended outcome.

Alternative approaches for recreation and parks provision in the dense inner core where poor people and immigrants predominate, such as art parks, community gardens, vest-pocket parks, and tot-lots are appearing but are unrecognized as legitimate open-space amenities. Additionally, there is evidence that Latinos perceive the value of nature in the dense inner core even more than their Anglo counterparts. Preliminary survey analysis shows that Latinos have a high comprehension of, for example, the environmental contributions trees make to reducing air pollution and cooling the ambient temperatures (Pincetl and Longcore, 2002). Further, surveys on environmental attitudes done for the California League of Conservation Voters (2001) confirm that Latinos have the highest concern about environmental quality of all groups. This points to the potential need for reconsidering the approach to parks and recreation facilities by those actively promoting them, though there is no evidence of any work being done in this area by those involved. Additionally, Loukaitou-Sideris (1995) has found that among Asian park users in Los Angeles, there is aversion to structured recreation facilities; this group prefers well-landscaped leisure grounds. This evidence-gathered when people were asked their preferences-points to 
the need for consulting with potential park recipients before making decisions about who gets what where.

In 2000, a statewide coalition of environmental nonprofits came together to place Propositions 12 and 13 on the state ballot. They were sponsored by state legislators, copying the Meral model: lots of specific funding for many projects all over the state, including a sizable amount of money for the Los Angeles area, all arrived at through negotiation and consultation with local public and nonprofit organizations. Proposition 12, the "Safe Neighborhood Parks, Clean Water, Clean Air and Coastal Protection Bond Act of 2000," and Proposition 13, "The Safe Drinking Water, Clean Water, Watershed Protection, and Flood Protection Bond Act," emerged from the California Environmental Dialogue (CED), a coalition of business and environmental groups who worked with legislators to provide around $\$ 5$ billion in new funds for parks, habitat, open space, and watersheds. Both these multibillion dollar statewide ballot initiatives passed.

\section{The New Urban Governance and the Nonprofit Sector}

In 1978, Proposition 13 created a fiscal void at the local level and a leadership void. With the increasing difficulty of localities to meet basic needs - including health, housing, education, and parks - through traditional taxation mechanisms and funds from the state and federal government, a new approach was required. In the area of funding for parks and open space, clearly the nonprofit sector played a leadership role in building public/private coalitions to get additional public funds that would be used to direct land-use decisions. But there is another aspect to this partnership. With the addition of the nonprofit sector to the local urban regime, both business interests and government benefit by bringing in a partner that can assist in developing more "cost-effective" solutions (Jones, 1998): often nonprofits have slimmer staffs, lower salaries than their state counterparts, and do not require the same rates of return as do their business counterparts. Businesses benefit by having a more attractive environment for investments, environmental organizations achieve the open spaces they desire, and, finally, local government is assisted through the nonprofit mobilization of resources that governments themselves are not able to mobilize. And in fact, nonprofit park acquisition and management is now well established. Even though small, the competitive grants built into Proposition A, Proposition $\mathrm{K}$, and the 2000 statewide Propositions 12 and 13 channel funds on a competitive basis to nonprofits. Required to show they have sufficient capacity to manage the amenity over a 30-year lifetime, qualified nonprofits end up being those that had the capacity to engage in negotiation-they were sufficiently sophisticated to participate as members of the local urban regime. Boys and Girls Clubs, local Conservation Corps, and longstanding community advocacy organizations such as the Watts Labor Community 
Action Committee (started after the 1964 Watts riots) that have strong ties to local politicians became the favored petitioners, excluding such less wellestablished groups as community gardeners, land art organizations, and new groups. Integrating nonprofits enables the further shifting responsibility away from the state and enables developing governance solutions to the provision of public services, such as parks.

Private land conservancies such as the Trust for Public Land (TPL) have emerged as key players in this transformation. TPL was deeply involved in crafting Propositions 12 and 13, and was then instrumental in securing $\$ 83$ million for revitalizing landscapes along the Los Angeles River. With its sophistication and organizational capacity, it "identified the best conservation projects along the river-working with each municipality to secure its support, continuing complex negotiations with landowners, and preparing proposals for state representatives to review" (TPL, 2001). TPL, with the belief that the Los Angeles River should be revitalized, went to local cities in Los Angeles County and worked to convince them that they should partner to get state funds to create parks in their jurisdictions along the river. Maywood, a small city in southeast Los Angeles, had no public park, and the local government lacked the internal capacity to organize an application for state park bond money. Poor and crowded, Maywood saw an alliance with TPL as advantageous. Similarly, TPL has been working with the City of Los Angeles and other environmental nonprofits to apply for state funds for these open-space amenities. TPL is currently involved in purchasing 193 acres of former wetlands in the controversial Playa Vista project. It is looking to identify a government agency and sources of public funding to buy the parcels (Stremfel, 2001). Typically, TPL will purchase land, using a combination of public and private funds (mostly public), and then turn them over to a public agency for management over the long term. With its 2 percent overhead, it offers economical, efficient, and professional services that are hard to beat.

\section{The Nomprofit Sector}

The conjunction of these events and players leads to several important new developments regarding who is involved in the allocation of land in the state and in Los Angeles, and under what assumptions. With the de facto shrinking of home rule (the ability of cities to develop their own charter, regulate their own land use, and generate their own revenues, established in 1914), and the retrenchment of public monies, nonprofits have taken the place of the Chamber of Commerce and its business members of yore to lead the way in proactive long-term land-use planning for public amenities, environmental quality, and to make Los Angeles a better place to live.

Globally, there has been an "associational revolution" involving a striking upsurge of organized private, voluntary activity (Salamon, 1994). The 
nonprofit or tax-exempt sector involves at least 1.2 million public-serving organizations (including the huge health sector). Historically, as Salamon explains, during the late 19th century, Americans came to revere nonprofit corporations. Support for the nonprofit sector up until the New Deal was a central part of the conservative ideology used to fend off proposals for expanded government social welfare protections. There was a mythic belief in the power of purely private, voluntary approaches to solve the problems in society. During the period of the Great Society in the 1960s, government supported the nonprofit sector's involvement in social welfare activity because there remained hostility to the government itself providing those services. The nonprofit sector grew tremendously during this period, only to face retrenchment in the 1980s during the conservative fiscal policies of the Reagan era (Salamon, 1999). Still, the voluntary sector in the United States is central to everyday political and economic life and is an essential engine in contemporary social change (Wolch, 1990). There is an increased interdependency of government and nonprofit organizations and a pervasive mingling of public and private funds and functions that lead to a blurring of traditional boundaries between the state, the market, and the "third sector" in the production and distribution of public goods and services (Kramer, 1990).

In this manner, the nonprofit sector picks up the slack of its partner-the state. With increasing devolution of state responsibilities to domestic nonprofit sectors, the nonprofits in fact become part of the emerging governance structure and may increasingly lose their relatively independent point of view. The nonprofit sector in becoming an innovator for funding mechanisms, a power broker, an arbiter of acceptable open-space and park projects, risks usurping public participation and debate, while imposing its values about what kinds of parks and open spaces are appropriate for whom. They are able to operate on two levels. One involves directing resources to local agencies through the language of the propositions-this serves to enlist agency support for the proposition and to boost their budgets. Second, they are able to establish the parameters of who and what gets funded beyond traditional park and recreation providers through the competitive funds that have been included in the propositions.

A recent development illustrates this potential. A grassroots coalition of community organizations, community gardeners, and tree planters (the Verde Coalition) recently put forward a proposal to create a land-trust mechanism in the City of Los Angeles to enable community groups to create small pocket parks in their neighborhoods and receive city insurance protection and assistance. This proposal was passed by the City Council in 2001 and referred to the City Legislative Analysts Office (CLA) for refinement. The CLA's office has been consulting exclusively with the TPL about the proper structure for the land trust, excluding the groups and organizations that put the proposal forward in the first place. TPL is suggesting a land trust with a board made up of the business-sector elite, 
whereas the original land-trust proponents want a board made up of their peers. $^{2}$ TPL, a national nonprofit, is the de facto stand-in for the nonprofit sector.

\section{Conclusion}

Park advocacy for southern California was largely spurred by environmentalist concerns about sprawl and its effects on habitat on the urban fringe (Edmiston, 2000). Environmental nonprofits provided the leadership for finding new sources of funding in response to profound structural changes in urban and state financing. They developed a partnership strategy, involving state and local governments, politicians, other nonprofits, and selected private-sector partners, to forge park bond measures that would reward all participants. They built on longstanding concepts of who should get what facilities, reinforcing those concepts by crafting the park bond measures to favor traditional types of groups and organizations. Their actions have had significant land-use effects, distributing benefits unevenly across the region.

This approach differs somewhat from that described by Lineberry and Sharkansky and by Mladenka in his study of park distribution in Chicago. Political scientists have looked at the distribution of who gets what services and amenities, how and why. Mladenka, in his study of Chicago, showed that park distribution was largely unaffected by traditional notions of machine politics, and that they were a function of group demands and protests (1980:993). In Los Angeles, nearly 20 years later, other factors prevailed, reflecting "a new urban politics." Nonprofit park advocates captured the sentiment that the Los Angeles area had long suffered a lack of parks and open space compared to other large metropolitan areas and that it was time to rectify the situation. (Among all major cities, Los Angeles spends the least per capita on parks (Harnik, n.d.).) One can see this approach as a component of urban boosterism, of making the region a more attractive and competitive one through its provision of open-space amenities. Here it was the nonprofit sector that was in the leadership role, not governmental bureaucracies, politicians, or traditional business interests; nonprofits negotiated with governmental bureaucracies, enlisting their support, and with politicians to shift public resources (putting a bond measure on the ballot) their direction.

Urban regime theory offers a useful explanatory framework for understanding how cities work in the contemporary context. Yet, as Cox (1997), Gibbs and Jonas (2000), Painter (1997), and others have pointed out, urban regime theory's overall single-minded focus on the economic sphere has meant overlooking other influences and actors. Gibbs and Jonas (2000)

\footnotetext{
${ }^{2}$ Verde Coalition email message re: progress of land trust proposal, 12/19/01. Author on cc: list.
} 
draw attention to the role of environmental rules, regulations, and concerns in shaping local urban regimes in southern California, but these rules and regulations are a result of people, groups, and organizations taking political action to put them in place. Environmental nonprofits have been at the forefront of this activity, as well as instrumental in creating new approaches for funding what they consider important. Nonprofits, given their financial, intellectual, and political resources, need to be taken into consideration in understanding the workings, values, and actions of local urban regimes. They seem to engage in partnerships, to forge new governance arrangements, to leverage government resources, and to participate in the allocation of land in ways similar to how traditional economic actors of urban regimes have been defined. Civil society has been a neglected partner in urban regimes; its role in shaping the entrepreneurial activities of cities needs far greater understanding. This article hopes to be an initial step in that direction.

\section{REFERENCES}

Bradley, Tom. Various years. Budget transmittal letters to the City Council of Los Angeles.

California League of Conservation Voters, Education Fund. 2001. Telephone Survey of Attitudes Toward the Environment. Available at 〈www.ecovote.org.〉

Cox, Kevin R. 1997. "Governance, Urban Regime Analysis, and the Politics of Local Economic Development.” In M. Lauria, ed., Reconstructing Urban Regime Theory, Regulating Urban Politics in a Global Economy. Thousand Oaks, Cal.: Sage.

Cox, Kevin, and Andy Mair. 1988. "Locality and Community in the Politics of Local Economic Development." Annals of the Association of American Geographers 78:307-25.

Cranz, Galen. 1989. The Politics of Park Design, A History of Urban Parks in America. Cambridge: MIT Press.

Davies, Jonathan S. 2002. "Urban Regime Theory: A Normative-Empirical Critique." Journal of Urban Affairs 24(1):1-17.

Draper, Joan E. 1996. "The Art and Science of Park Planning in the United States: Chicago's Small Parks, 1902-1905." In Mary Corbin Sies and Christopher Silver, eds., Planning the Twentieth-Century American City. Baltimore, Md.: Johns Hopkins University Press.

Edmiston, Joseph. 2000. Executive Director of the Santa Monica Mountains Conservancy. Personal interview with author. Santa Monica Mountains Conservancy office at The River Center. Los Angeles, Cal.

Elkin, Stephen. 1987. City and Regime in the American Republic. Chicago, Ill.: University of Chicago Press.

Fogelson, Robert. [1967] 1993. The Fragmented Metropolis; Los Angeles, 1850-1930. Berkeley, Cal.: University of California Press.

Foglesong, Richard E. 1986. Planning the Capitalist City, The Colonial Era to the 1920s. Princeton, N.J.: Princeton University Press.

Fulton, William. 1997. The Reluctant Metropolis. Point Arena: Solano Press. 
Gibbs, David, and A. E. Jonas. 2000. "Governance and Regulation in Local Environmental Policy: The Utility of a Regime Approach.” Geoforum 31:299-313.

Hall, Tim, and Phil Hubbard, eds. 1998. The Entrepreneurial City, Geographies of Politics, Regime and Representation. New York: John Wiley and Sons.

Harnik, Peter. n.d. Inside City Parks. Washington, D.C.: Urban Land Institute, The Trust for Public Land.

Hester, Jr., Randolph T., Nova J. Blazej, and Ian S. Moore. 1999. "Whose Wild? Resolving Cultural and Biological Diversity Conflicts in Urban Wilderness." Landscape Journal 18(2):137-44.

Hise, Greg, and William Deverell. 2000. Eden by Design, the 1930 Olmsted-Bartholomew Plan for the Los Angeles Metropolitan Region. Berkeley, Cal.: University of California Press.

Hjelte, George. 1977. Footprints in the Parks, ltd. ed. Los Angeles, Cal.: Public Service Publications.

Jessop, Bob. 1995. "The Regulation Approach, Governance and Post-Fordism: Alternative Perspectives on Economic and Political Change." Economy and Society 24:307-33.

Jonas, Andrew E. G. 1997. "Regulating Suburban Politics: Suburban-Defense Transition." In M. Lauria, ed., Reconstructing Urban Regime Theory, Regulating Urban Politics in a Global Economy. Thousand Oaks, Cal.: Sage.

Jones, Martin. 1998. "Restructuring the Local State: Economic Governance or Social Regulation?” Political Geography 17(8):959-88.

Jordon III, William R. 1994. "Sunflower Forest: Ecological Restoration as the Basis for a New Environmental Paradigm.” In A. Dwight Baldwin Jr., Judith De Luce, and Carl Pletsch, eds., Beyond Preservation, Restoring and Inventing Landscapes. Minneapolis, Minn.: University of Minnesota Press.

Kirlin, J. J., and D. R. Marshall. 1988. "Urban Governance and the New Politics of Entrepreneurship." Pp. 348-73 in M. McGeary and L. Lynn, eds., Urban Change and Poverty. Washington D.C.: National Academic Press.

Kramer, Ralph M. 1990. "Introduction." In Jennifer Wolch, The Shadow State: Government and Voluntary Sector in Transition. New York: Foundation Center.

Lindbloom, C. E. 1977. Politics and Markets: The World's Political-Economic Systems. New York: Basic Books.

Lineberry, Robert, and Ira Sharkansky. 1978. Urban Politics and Public Policy, 3rd ed. New York: Harper and Row Publishers.

Loukaitou-Sideris, Anastasia. 1995. "Urban Form and Social Context: Cultural Differentiation in the Uses of Urban Parks." Journal of Planning Education and Research 14:89-102.

Macleod, G. 1997. "Entrepreneurial Spaces, Hegemony and State Ideology: The Political Shaping of Privatism in Lowland Scotland.” Environment and Planning A 31:345-75.

O'Connor, Justin. 1998. "Popular Culture, Cultural Intermediaries and Urban Regeneration." In Tim Hall and Phil Hubbard, eds., The Entrepreneurial City, Geographies of Politics, Regime and Representation. New York: John Wiley and Sons.

Olmsted Brothers and Bartholomew and Associates, Consultants. 2000. "Parks, Playgrounds and Beaches for the Los Angeles Region." In G. Hise and W. Deverell, eds., Eden by Design, the 1930 Olmsted-Bartholomew Plan for the Los Angeles Metropolitan Region. Berkeley, Cal.: University of California Press. 
Painter, Joe. 1997. "Regulation, Regime and Practice in Urban Politics." In M. Lauria, ed., Reconstructing Urban Regime Theory, Regulating Urban Politics in a Global Economy. Thousand Oaks, Cal.: Sage.

1998. "Entrepreneurs are Made, Not Born: Learning and Urban Regimes in the

Production of Entrepreneurial Cities." In Tim Hall and Phil Hubbard, eds., The Entrepreneurial City, Geographies of Politics, Regime and Representation. New York: John Wiley and Sons.

Peterson, P. 1981. City Limits. Chicago, Ill.: University of Chicago Press.

Pincetl, Stephanie. 1999. Transforming California, the Political History of Land Use and Development. Baltimore, Md.: John Hopkins University Press.

Pincetl, Stephanie, and Travis Longcore. 2002. Preliminary telephone survey results regarding attitudes toward parks, recreation and open space for a 2 year research project on "Nature's Services." Funded by the Haynes Foundation of Los Angeles, Cal.

Press, Daniel. 1999. "Local Open-Space Preservation in California." Pp. 153-83 in Michael Kraft and Daniel A. Mazmanian, eds., Toward Sustainable Communities, Transition and Transformations in Environmental Policy. Cambridge: MIT Press.

Rhodes, R. A. W. 1996. “The New Governance: Governing Without Government.” Political Studies 44(4):652-67.

Rosenzweig, Roy. 1983. Eight Hours for What We Will, Workers and Leisure in an Industrial City, 1970-1920. Cambridge: Cambridge University Press.

Salamon, Lester M. 1994. "The Rise of the Nonprofit Sector." Foreign Affairs 73(3): $111-24$. 10(1):5-24.

Sassen, Saskia. 1996. Losing Control? Sovereignty in an Age of Globalization. New York: Columbia University Press.

Schrag, Peter. 1998. Paradise Lost, California's Experience, America's Future. Berkeley, Cal.: University of California Press.

Silva, Fred J. 1999. The State-Local Fiscal Relationship in California: A Changing Balance of Power. San Francisco, Cal.: Public Policy Institute of California.

Sprawl Hits the Wall, Confronting the Realities of Metropolitan Los Angeles. 2001. The Southern California Studies Center at the University of Southern California and the Brookings Institutions Center on Urban and Metropolitan Policy. Available at 〈www.usc.edu/urban〉.

Staehli, Lynn A., Janet E. Kodras, and Colin Flint. 1997. "Introduction.” In Lynn A. Staehli, Janet E. Kodras, and Colin Flint, eds., State Devolution in America, Implications for a Diverse Society, Urban Affairs Annual Review, Vol. 48. Thousand Oaks, Cal.: Sage Publications.

Stone, Clarence. 1989. Regime Politics: The Governing of Atlanta 1946-1988. Lawrence, Kan.: University of Kansas.

Stremfel, Michael. 2001. "Tug of War Ensuing Over Two Land Parcels.” Los Angeles Business Journal Oct. 29:36.

Sutton, S. B., ed. 1971. Civilizing American Cities; A Selection of Frederick Law Olmsted's Writings on City Landscapes. Cambridge: MIT Press.

Trust for Public Land (TPL). 2001. \$83 Million in Public Funds for the LA River Greenway. Available at $\langle$ http://www.tpl.org/ $\rangle$. 
Walters, Dan. 2001. "23 Years Later, Prop. 13 Still Altering California's Political Landscape." Sacramento Bee Nov. 14. Available at 〈sacbee.com〉.

Ward, Kevin. 1996. "Rereading Urban Regime Theory: A Sympathetic Critique." Geoforum 27(4):427-38.

Ward, Tricia. 2001. Commissioner, Los Angeles Commission on Youth, Children and Their Families. Personal interview.

Williams, Raymond. 1980. "Ideas of Nature," Problems in Materialism and Culture. London: Verso.

Wolch, Jennifer. 1990. The Shadow State: Government and Voluntary Sector in Transition. New York: Foundation Center. 